UDC 502.521:630.1.42

DOI: 10.37128/2707-5826-2021-3-15

\title{
ASSESSMENT OF THE ECOLOGICAL CONDITION OF AGRICULTURAL SOILS IN UKRAINE
}

YAKOVETS LIUDMYLA, Candidate of Agricultural Sciences, senior teacher, Vinnytsia National Agrarian University

The article presents the results of assessing the ecological condition of agricultural soils in Ukraine. The purpose of the research is to study the assessment of the ecological condition of agricultural soils in Ukraine.

The research results show that contamination with cesium-137 of above $37 \mathrm{kBq} / \mathrm{m}^{2}$ on the agricultural land in Ukraine covers 461.7 thousand hectares, among which arable lands occupy 345.9 thousand hectares. 8.8 million hectares of agricultural land have been examined, and it has been found that 12 regions remain contaminated with various toxicants.

It has been established that the largest areas of agricultural land contaminated with cesium137 can be found in Zhytomyr region - 156 thousand hectares, Cherkasy region - 76, Rivne region - 52, Chernihiv region - 52, Vinnytsia region - 50 and Kyiv region - 34 thousand hectares. In recent years, in Cherkasy and Vinnitsa regions, there have not been identified agricultural products contaminated at the levels that exceed permissible ones. In Rivne region, the most difficult situation is with the contamination of agricultural products with cesium-137, where more than 18.6 thousand hectares of peatlands are contaminated. Contamination of agricultural lands with strontium in Ukraine is observed on a much larger scale than those with cesium. Strontium-90 in the range of 0.74-5.55 $\mathrm{kBq} / \mathrm{m}^{2}$ contaminated 4.6 million hectares, which occupies $52 \%$ of the area under research. Research results indicate that the total area of contaminated land in Ukraine is about 9 million hectares, among them 4.2 million hectares are contaminated with radiation, 2.0 million hectares are contaminated with heavy metals, 2.8 million hectares are contaminated with toxicants of organic and inorganic origin. It has been established that contamination with heavy metals from agro-industrial sources to the levels approaching the maximum permissible level (MPL) is possible only on the lands where chemicals have been used for a long time without proper control. It has also been found that application of mineral fertilizers and traditional organic fertilizers in medium doses can raise the level of heavy metals in soils with the current values of MPC only for hundreds of years.

Key words: soil, mineral fertilizers, radionuclides, pesticides, heavy metals, contamination.

Tabl. 3. Ref. 15.

Formulation of the problem. One of the main components of the environment that performs vital biosphere functions is the soil cover. Soil and vegetation form a single system in nature. Degradation and loss of soil fertility leads to plant deprivation of the ecological basis for its existence. Restoration of the fertility of degraded soils involves restoration of the natural ecological balance of territories disturbed by man as a result of irrational economic activity [1, 2]. Therefore, nowadays the study of the assessment of the ecological condition of agricultural soils of Ukraine is an extremely important and urgent problem.

Analysis of recent research and publications. According to the research carried out by M.I. Khilko [3], the soil is a thin upper layer of the earth's surface, which has appeared as a result of its transformation under the influence of water, air, organisms and has a natural fertility. Soils consist of solid, liquid and gaseous parts, 
plants, animals, microorganisms and are one of the components of the biosphere, a basic component of any landscape [3, 4].

Soils perform the function of the habitat, accumulator and source of matter and energy for organisms, the intermediate chain between biological and geological cycles, a protective barrier and conditions of normal functioning of the biosphere as a whole $[5,6]$.

It is known from the literature that agroecological potential, i.e. the ability of soils to perform the function of the agricultural land, create optimal conditions for the growth and development of agricultural plants, as well as maintain ecological balance in agricultural landscapes and the habitat is determined by indicators characterizing humus layer thickness; nutrient content; level and mineralization of groundwater; biotic potential or bioproductivity of land; soil resistance to contamination; contamination with radionuclides, heavy metals, pesticides and mineral fertilizers, taking into account natural characteristics of soils; unfavorable natural and anthropogenic processes [7, 8].

Man-made pollution is a significant environmental damage to soils. It depends on the type of soil, the amount of industrial waste, heavy metals, radionuclides, pesticides and fertilizers.

One of the potential pollutants of land resources is industrial emissions and intensive chemicalization of agriculture. Enterprises of ferrous and nonferrous metallurgy, light industry, CHP are the common sources of soil contamination with heavy metals in the cities. The risk of soil contamination is determined not only by the content of heavy metals, but also by the hazard class of individual toxicants. The first class of harmfulness includes arsenic, cadmium, mercury, selenium, lead, zinc, fluorine, benzopyrene; the second one includes boron, cobalt, nickel, copper, molybdenum, antimony, chromium; the third one includes barium, vanadium, tungsten, manganese, strontium. The content of toxicants in the soils can be assessed by both gross and mobile forms of elements. Many of them can lead to human morbidity $[9,10]$.

It should be noted that soil contamination with chemical plant protection products is complex. Although the reduction of pesticide use by several times in recent years has helped to reduce contamination of soil and agricultural products with pesticides, but it has not changed the situation significantly. This is caused by the fact that the residual amount of pesticides can be found in the soil for a long time [11, 12].

O.P. Tkachuk, argues that about $50 \%$ of the total crop growth is provided by mineral fertilizers, $25 \%$ by the cultivation technologies. However, we should not forget that improper use of mineral fertilizers like nitrogen, phosphorus, potassium, complex and others is accompanied by undesirable side effects, i.e. environmental pollution and it is explained by the unbalanced use of fertilizers, deviations from the norms of their application [2].

According to the analytical results of research [13], it has been established that some types of mineral fertilizers can increase the acidity of soils, accumulation of dangerous residues in them. Plants absorb only $50 \%$ of nitrogen and $10-20 \%$ of 
phosphorus fertilizers, the rest are washed away by precipitation.

Under unbalanced use of mineral fertilizers, increased amounts of nitrogen, phosphorus, potassium can accumulate in the natural environment, and this leads to acidification of the soil solution, groundwater pollution due to filtration of fertilizers, increased content of nitrates, sulfates, chlorides, accumulation of residual nitrate in plant products, contamination of water reservoirs, rivers with fertilizer residues due to erosion, which harms health of humans, animals and fisheries [14].

In recent years, Ukraine's agricultural landscapes have been constantly exposed to various types of radiation pollution, i.e. atmospheric emissions of radionuclides due to the testing of nuclear weapons and waste from the processing of raw materials at nuclear fuel cycle enterprises. In view of this, aspects of the study of assessment of the ecological condition of agricultural soils are relevant and of considerable scientific interest.

The purpose of the research is to study the assessment of the ecological condition of agricultural soils in Ukraine.

Presentation of the main material. According to analytical data [9], it has been established that pollution of the environment with chemicals and radionuclides has significantly affected the soil cover. As a result, physical and chemical properties of soils deteriorate and the area of degraded lands increases [12].

Generalized data on the collection, analysis and radiological survey of arable lands of Ukraine shows that contamination with cesium-137 above $37 \mathrm{kBq} / \mathrm{m}^{2}$ on the agricultural lands of Ukraine is spread over 461.7 thousand hectares, among them 345.9 thousand hectares are arable lands. Areas contaminated with toxic substances remain in 12 regions, where 8.8 million hectares have been observed [9].

According to the Internet sources, the largest areas of agricultural lands contaminated with cesium-137 are distributed in the following regions: Zhytomyr 156 thousand hectares, Cherkasy - 76, Rivne - 52, Chernihiv - 52, Vinnytsia - 50, Kyiv - 34 thousand ha. In recent years, in Cherkasy and Vinnytsia regions, there have not been found agricultural products contaminated at the levels that exceed permissible ones. This is due to the predominance of mid-loam chernozems in the soil cover, where the migration capacity of radionuclides is limited [5].

In Rivne region, the most difficult situation is with the contamination of agricultural products with cesium-137, where more than 18.6 thousand hectares of peatlands are contaminated. The migration of radionuclides in these areas is the most intense [5]. Contamination of agricultural lands with strontium in Ukraine is observed on a much larger scale than those with cesium. Strontium-90 in the range of 0.74-5.55 $\mathrm{kBq} / \mathrm{m}^{2}$ contaminated 4.6 million hectares, which occupies $52 \%$ of the area under research. The intensive spread of this radionuclide on the territory of Ukraine is due to global emissions of strontium-90 during the testing of nuclear weapons in the atmosphere [5]. Scientists claim that contamination of lands with strontium-90 as a result of the Chernobyl disaster was less intense and spread mainly within the exclusion zone and adjacent areas, but in aerosol outbursts strontium spread much further $[11,15]$. In general, today the radiation situation in the contaminated areas has 
significantly improved compared to the early post-accident period. This is due to natural autorehabilitation processes, a set of countermeasures aimed at strengthening biogeochemical barriers to block radionuclides in soils, which has reduced radiation contamination of local food products and enhanced radioecological monitoring of soils and agricultural products, their radiological control and precise compliance with the recommendations concerning agricultural production [15].

The total area of contaminated lands in Ukraine is about 9 million hectares, among them 4.2 million hectares are radiation-contaminated lands; 2.0 million hectares are the lands contaminated with heavy metals; 2.8 million hectares are the lands contaminated with toxicants of organic and inorganic origin [7].

Chemicals caused by the emissions and wastes are divided into three classes according to the degree of hazard (Table 1).

\section{Classes of pollutants by the degree of hazard}

\begin{tabular}{|l|c|}
\hline \multicolumn{1}{|c|}{ Class } & Chemical substance \\
\hline I. Very hazardous & $\begin{array}{r}\text { Arsenic (As), cadmium (Cd), mercury (Hg), selenium (Se), } \\
\text { lead (Pb), fluorine (F), benzopyrene }\end{array}$ \\
\hline II. Moderately hazardous & $\begin{array}{r}\text { Boron (B), cobalt (Co), nickel (Ni), molybdenum (Mo), } \\
\text { copper (Cu), chromium (Cr) }\end{array}$ \\
\hline III. Low hazardous & $\begin{array}{r}\text { Barium (Ba), vanadium (V), tungsten (W), manganese } \\
(\mathrm{Mn}), \text { strontium (Sr), acetophenone }\end{array}$ \\
\hline
\end{tabular}

Source: formed based on the reference [12].

Indicators for determining the hazard class of chemicals are set according to Table 2 .

Table 2

\section{Hazard classes of chemicals}

\begin{tabular}{|l|c|c|c|}
\hline \multirow{2}{*}{ Indicator } & \multicolumn{3}{c|}{ Norm for hazard class } \\
\cline { 2 - 4 } & I & II & III \\
\hline Toxicity, LD S0 $^{*}$ & $<200$ & $200-1000$ & $>1,000$ \\
\hline Persistence in the soil, months & $>12$ & $6-12$ & $6-12$ \\
\hline MPC in the soil, mg/kg & $<0.2$ & $0.2-0.5$ & $>0.5$ \\
\hline Migration & Migrating & $\begin{array}{c}\text { Poorly } \\
\text { migrating }\end{array}$ & Non-migrating \\
\hline Persistence in plants, months of nutritional value of & High & Moderate & None \\
\hline $\begin{array}{l}\text { Impact on the } \\
\text { agricultural products }\end{array}$ & & & \\
\hline
\end{tabular}

Source: formed based on the reference [12].

Heavy metals are one of the potential soil contaminants. Sources of heavy metals are divided into natural and man-made. Natural sources include weathering of rocks and minerals, erosion processes, volcanic activity. Man-made sources of soil contamination with heavy metals include air emissions from ferrous metallurgy, vehicles, liquid and solid municipal waste, pesticides, organic and mineral fertilizers (Table 3) [12]. 
Therefore, when characterizing the general status of soil contamination with heavy metals, it should be considered that its dangerous level, which exceeds MPC,

Table 3

\section{Sources of soil contamination with heavy metals}

\begin{tabular}{|c|c|c|c|c|c|c|}
\hline Element & $\begin{array}{c}\text { Irrigation and } \\
\text { sewage }\end{array}$ & $\begin{array}{c}\text { Phosphorus } \\
\text { fertilizers }\end{array}$ & $\begin{array}{c}\text { Limestone } \\
\text { materials }\end{array}$ & $\begin{array}{c}\text { Nitrogen } \\
\text { fertilizers }\end{array}$ & $\begin{array}{c}\text { Organic } \\
\text { fertilizers }\end{array}$ & Pesticides \\
\hline $\mathrm{As}$ & $2-26$ & $2-1,200$ & $0.1-24$ & $2.2-120$ & $3-25$ & $22-60$ \\
\hline $\mathrm{Cd}$ & $2-1,500$ & $0.1-170$ & $0.04-0,1$ & $0.05-8.5$ & $0.3-0.8$ & - \\
\hline $\mathrm{Co}$ & $2-260$ & $1-12$ & $0.4-3.0$ & $5.4-12$ & $0.3-24$ & - \\
\hline $\mathrm{Cr}$ & $20-40,000$ & $66-245$ & $10-15$ & $3.2-19$ & $5.2-55$ & - \\
\hline $\mathrm{Cu}$ & $50-3,300$ & $1-300$ & $2-125$ & $1-15$ & $2-60$ & $15-50$ \\
\hline $\mathrm{F}$ & $2-740$ & $8,500-38,000$ & 300 & - & 7 & $18-45$ \\
\hline $\mathrm{Hg}$ & $0.1-55$ & $0,01-1,2$ & 0.05 & $0.3-2.9$ & $0.09-0.2$ & $0.8-42$ \\
\hline $\mathrm{Mn}$ & $60-3,900$ & $40-2,000$ & $40-1,200$ & - & $30-550$ & - \\
\hline $\mathrm{Mo}$ & $1-40$ & $0.1-60$ & $0.1-15$ & $1-7$ & $0.05-3$ & - \\
\hline $\mathrm{Ni}$ & $16-5,300$ & $7-38$ & $10-20$ & $7-34$ & $7.8-30$ & - \\
\hline $\mathrm{Pb}$ & $50-3,000$ & $7-225$ & $20-1,250$ & $2-27$ & $6.6-15$ & 60 \\
\hline $\mathrm{Se}$ & $2-9$ & $0.5-25$ & $0.08-0.1$ & - & 2.4 & - \\
\hline $\mathrm{Sn}$ & $40-700$ & $3-19$ & $0.5-4.0$ & $1.4-16$ & 3,8 & - \\
\hline $\mathrm{Zn}$ & $700-49,000$ & $50-1,450$ & $10-450$ & $1-42$ & $15-250$ & $1.3-25$ \\
\hline $\mathrm{Sou}$ & $\mathrm{F}$ & & & & \\
\hline
\end{tabular}

Source: formed on the basis of the reference [12].

was found mainly near metallurgical enterprises within a radius of 10-12 km and along high-traffic roads. In these areas and places the agricultural use of soils should be specialized, it is advisable to exclude them from usual crop rotations.

It should be noted that contamination with heavy metals from agro-industrial sources to the levels close to MPC is only possible on the lands where chemicals, such as pesticides or wastewater, have been used for a long time without proper control. Application of mineral fertilizers and traditional organic fertilizers in medium doses can raise the level of heavy metals in soils to the current values of MPC only during hundreds of years [12].

It should be noted that the most probable objects on which it is possible to expect increase in level of pollution by heavy metals and for which inspection is necessary, are: suburban zones of the big industrial centers; vegetable crop rotations with a high level of saturation with fertilizers and pesticides; fields with traditional wastewater use; areas where pesticides are systematically applied.

Conclusions and prospects for further research. The obtained research results give grounds to believe that soil pollution leads to significant environmental and economic damage: crop yields fall, forest productivity decreases, certain areas of land are withdrawn from economic use, and the condition of the environment deteriorates. Control of these changes and the formation of appropriate programs to stop the degradation and reproduction of soil fertility is an extremely important task and needs to be improved. 


\section{Список використаної літератури}

1. Скидан О. В. Інституційні засади формування аграрної політики України: монографія. Житомир: Полісся. 2010. 576 с.

2. Ткачук О. П. Проблеми та перспективи ведення екологічно-збалансованого землеробства в Україні: monografia pokonferencyjna. Science, Research, Development. Berlin, 30.08.2019-31.08.2019. № 19. S. 47-49.

3. Хилько М.I. Екологічна безпека України: навчальний посібник. Київ, 2017. $267 \mathrm{c}$.

4. Яковець Л. А. Агроекологічна оцінка стану едафотопів Лісостепу правобережного залежно від інтенсивності хімізації землеробства. Polish Journal of Science. 2020. № 27. Vol. 1. P. 9-16.

5. Забруднення радіонуклідами сільськогосподарських угідь. URL: http://www.iogu.gov.ua/monitorynh-objektiv-dovkillya/radionuklidy.

6. Ткачук О. П., Яковець Л. А. Динаміка виробництва зерна та внесення мінеральних добрив під зернові культури у Вінницькій області. «Сільське господарство та лісівниџтво». 2017. Вип. 6 (Том 1). С. 141-148.

7. Ткачук О. П., Овчарук В. В. Потенціал біомаси побічної продукції рослинництва для удобрення грунту. Scientific achievements of modern society. Abstracts of IX international scientific and practical conference. April 28-30. 2020. Liverpool. P. 1069-1076.

8. Мазур В. А., Вергеліс В. I. Оцінка придатності грунтів НДГ «Агрономічне» для вирощування органічної продукції за вмістом важких металів. «Сільське господарство та лісівництво». 2018. № 9. С. 165-177.

9. Гуторов О. I. Проблеми сталого землекористування у сільському господарстві: теорія, методологія, практика: монографія. Харків: ХНАУ. 2010. $405 \mathrm{c}$.

10.Яковець Л. А. Мінеральні добрива як токсиканти грунтів Лісостепу Правобережного. Ефективність використання екологічного аграрного виробництва: Збірник тез Міжнародної науково-практичної конференції. (Київ, 2 листопада 2017 р.). Київ. 2017. С. 179-182.

11.Разанов С. Ф., Ткачук О.П. Інтенсивна хімізація землеробства - як передумова забруднення зернової продукції важкими металами. Технологія виробництва і переробки продукиії твариннищтва. 2017. № 1-2 (134). С. 70-75.

12.Мазур В. А., Ткачук О.П., Яковець Л.А. Екологічна безпека зернової та зернобобової продукції: монографія. Вінниця: Твори, 2020. 442 с.

13.Мазур В. А., Кравчук Г. І., Гончарук Г. С. Еколого-збалансоване використання маргінальних земель при вирощуванні енергетичних культур. «Сільське господарство та лісівниитво». 2019. № 15. С. 5-20.

14.Mazur V.A., Yakovets L.A. Influence of the systematic application of fertilizers on the intensity of accumulation of nitrates in agricultural crops. Annali d'Italia. 2021. № 17. Vol. 1. P. 18-24.

15. Yakovets L. Toxic and ecological assessment of agricultural products of agrocenozes of the Right bank forest steppe depending on the intensity of 
agricultural chemistry. The scientific heritage (Budapest. Hungary). 2021. № 59 (59). Vol. 2. P. 19-25.

\section{References with transliteration}

1. Skydan O. V. (2010). Instytutsiyni zasady formuvannya ahrarnoyi polityky Ukrayiny [Institutional principles of formation of agrarian policy of Ukraine]. Monohrafiya. Zhytomyr: Polissya. 576 [in Ukrainian].

2. Tkachuk O.P. (2019). Problemy ta perspektyvy vedennya ekolohichnozbalansovanoho zemlerobstva v Ukrayini [Problems and prospects of ecologically balanced agriculture in Ukraine]. Monografia pokonferencyjna. Science, Research, Development 19. 47-49 [in Berlin].

3. Khyl'ko M. I. (2017). Ekolohichna bezpeka Ukrayiny: navchal'nyy posibnyk [Ecological security of Ukraine]. Kyiv. 267 [in Ukrainian].

4. Yakovets' L. A. (2020). Ahroekolohichna otsinka stanu edafotopiv Lisostepu pravoberezhnoho zalezhno vid intensyvnosti khimizatsiyi zemlerobstva [Agroecological assessment of the state of edaphotopes of the Forest-Steppe of the

right bank depending on the intensity of chemicalization of agriculture]. Polish Journal of Science. № 27. Vol. 1. 9-16 [in Polish].

5. Zabrudnennya radionuklidamy sil's'kohospodars'kykh uhid' [Contamination of agricultural lands with radionuclides] URL: http://www.iogu.gov.ua/monitorynh-objektiv-dovkillya/radionuklidy.

6. Tkachuk O. P., Yakovets' L. A. (2017). Dynamika vyrobnytstva zerna ta vnesennya mineral'nykh dobryv pid zernovi kul'tury u Vinnyts'kiy oblasti [Dynamics of grain production and application of mineral fertilizers for grain crops in Vinnytsia region]. Sil`s `ke gospodarstvo ta lisivny`cztvo - Agriculture and forestry. Issue. 6. Vols. 1. 141-148 [in Ukrainian].

7. Tkachuk O. P., Ovcharuk V. V. (2020). Potentsial biomasy pobichnoyi produktsiyi roslynnytstva dlya udobrennya hruntu [Biomass potential of crop byproducts for soil fertilization]. Scientific achievements of modern society. Abstracts of IX international scientific and practical conference. April 28-30. Liverpool. 1069-1076 [in Liverpool].

8. Mazur V. A., Verhelis V. I. (2018). Otsinka prydatnosti hruntiv NDH «Ahronomichne» dlya vyroshchuvannya orhanichnoyi produktsiyi za vmistom vazhkykh metaliv [Assessment of the suitability of NDG «Agronomichesky» soils for growing organic products on the content of heavy metals]. Sil's ke gospodarstvo ta lisivny 'cztvo - Agriculture and forestry. № 9. 165-177 [in Ukrainian].

9. Hutorov O. I. (2010). Problemy staloho zemlekorystuvannya u sil's'komu hospodarstvi: teoriya, metodolohiya, praktyka: monohrafiya [Problems of sustainable land use in agriculture]. Kharkiv: KHNAU. 405 [in Ukrainian].

10. Yakovets' L. A. (2017). Mineral'ni dobryva yak toksykanty gruntiv Lisostepu Pravoberezhnoho [Mineral fertilizers as soil toxicants of the Forest-Steppe of the Right Bank]. Efektyvnist' vykorystannya ekolohichnoho ahrarnoho vyrobnytstva: Zbirnyk tez Mizhnarodnoyi naukovo-praktychnoyi konferentsiyi. 
(Kyyiv, 2 lystopada 2017 r.). 179-182 [in Ukrainian].

11. Razanov S. F., Tkachuk O. P. (2017). Intensyvna khimizatsiya zemlerobstva - yak peredumova zabrudnennya zernovoyi produktsiyi vazhkymy metalamy [Intensive chemicalization of agriculture - as a prerequisite for contamination of grain products with heavy metals].Tekhnolohiya vyrobnytstva i pererobky produktsiyi tvarynnytstva. - Technology of production and processing of livestock products. № 1-2 (134). 70-75 [in Ukrainian].

12. Mazur V.A., Tkachuk O.P., Yakovets' L.A. (2020). Ekolohichna bezpeka zernovoyi ta zernobobovoyi produktsiyi. [Ecological safety of grain and legume products]. Monohrafiya. Vinnytsya: Tvory. 442 [in Ukrainian].

13. Mazur V. A., Kravchuk H. I., Honcharuk H. S. (2019). Ekolohozbalansovane vykorystannya marhinal'nykh zemel' pry vyroshchuvanni enerhetychnykh kul'tur. [Ecologically balanced use of marginal lands in the cultivation of energy crops]. Sil's 'ke gospodarstvo ta lisivny 'cztvo - Agriculture and forestry. № 15. 5-20 [in Ukrainian].

14. Mazur V.A., Yakovets' L.A. (2021). Vplyv systematychnoho zastosuvannya dobryv na intensyvnist' nakopychennya nitrativ $\mathrm{v}$ sil's'kohospodars'kykh kul'turakh [Influence of the systematic application of fertilizers on the intensity of accumulation of nitrates in agricultural crops]. Annali d'Italia. № 17. Vol. 1. 18-24. [in Annali d'Italia].

15. Yakovets' L. A. (2021). Toksyko-ekolohichna otsinka sil's'kohospodars'koyi produktsiyi ahrotsenoziv lisostepu pravoberezhnoho zalezhno vid intensyvnosti khimizatsiyi zemlerobstva [Toxic and ecological assessment of agricultural products of agrocenozes of the Right bank forest steppe depending on the intensity of agricultural chemistry. The scientific heritage (Budapest. Hungary). № 59 (59). Vol. 2.19-25 [in Budapest].

\section{АНОТАЦІЯ \\ ОЦІНКА ЕКОЛОГІЧНОГО СТАНУ СІЛЬСЬКОГОСПОДАРСЬКИХ ІРУНТІВ УКРАЇНИ}

У статті представлено результати оцінки екологічного стану сільськогосподарських трунтів України. Мета досліджень полягала у вивченні оцінки екологічного стану сільськогосподарських трунтів Украӥни.

Результати досліджень показали, щзо забруднення иеезієм-137 вище $37 \kappa Б \kappa / \mathrm{M}^{2}$ на сільськогосподарських угіддях України поширене на 461,7 тис. га, з них орних земель-345,9 тис. га. Було обстежено 8,8 млн. га сільськогосподарських угідь, i встановлено, щзо 12 областей зберігають забрудненні площуі різними токсикантали. Встановлено, щчо найбільші площі сільськогосподарських угідь, забруднених иезієм-137, поширені в Житомирській області- 156 тис. га, Черкаській області- 76, Рівненській області - 52, Чернігівській області - 52, Вінниџькій області- 50 та Київській області - 34 тис. га. Протягом останніх років у Черкаській $i$ Вінницькій областях - одержання сільськогосподарської продукиії, забрудненої вище допустимих рівнів не виявлено. Найскладніша ситуація щуодо забруднення сільськогосподарської продукції цеезієм-137, де забруднено понад 18,6 тис. га торфовищ склалась у Рівненській області.

Дослідженнями встановлено, щฺо забруднення сільськогосподарських трунтів Украӥни строниієм спостерігається в значно більших масштабах, ніж иезієве, а саме, у межах 0, 74-5,55 $\kappa Б \kappa / \mu^{2}$ стронцієм-90 забруднено 4,6 млн. га, щуо становить 52 \% від обстеженої площі. 
Результати досліджень свідчать, щзо загальна площза забруднених земель в Україні складає близько 9 млн. га, з них 4,2 млн. га - радіаційно забруднені, 2,0 млн. га - забруднені важкими металами, 2,8 млн. га - забруднені токсикантами органічного й неорганічного походження.

Встановлено, щуо забруднення важкими металами з агропромислових джерел до рівнів, щцо наближсаються до максимально допустимих (МДР), можливе тільки на землях, на яких засоби хімізачії застосовували тривалий час без належного контролю. А також встановлено, шчо внесення мінеральних добрив і традиційних

органічних добрив у середніх дозах здатне підняти рівень вмісту важких металів в грунтах до діючих нині значень МДК лише за сотні років.

Ключові слова: трунт, мінеральні добрива, радіонукліди, пестициди, важкі метали, забруднення.

Табл. 3. Лім. 15.

\section{АННОТАЦИЯ \\ ОЦЕНКА ЭКОЛОГИЧЕСКОГО СОСТОЯНИЯ СЕЛЬСКОХОЗЯЙСТВЕННЫХ ПОЧВ УКРАИНЫ}

В статье представлены результаты оценки экологического состояния сельскохозяйственных почв Украины. Цель исследований заключалась в изучении оценки экологического состояния сельскохозяйственных почв Украины.

Результаты исследований показали, что загрязнение иезием-137 выше $37 \kappa Б \kappa / \mathrm{m}^{2}$ на сельскохозяйственных угодьях Украины распространено на 461,7 тыс. га, из них пахотных земель - 345,9 тыс. га. Было обследовано 8,8 млн. га сельскохозяйственных угодий, $u$ установлено, что 12 областей сохраняют загрязнении площуади различными токсикантами. Установлено, что наибольшие площуади сельскохозяйственных угодий, загрязненных иезием137, распространенные в Житомирской области - 156 тыс. га, Черкасской области - 76, Ровенской области - 52, Черниговской области - 52, Винницкой области - 50 и Киевской области - 34 тыс. га. В течение последних лет в Черкасской и Винницкой областях получение сельскохозяйственной продукиии, загрязненной выме допустимых уровней не выявлено. Самая сложная ситуаџия по загрязнению сельскохозяйственной продукции иезием-137, где загрязнено более 18,6 тыс. га торфяников сложилась в Ровенской области. Исследованиями установлено, что загрязнение сельскохозяйственных почв Украины стронцием наблюдается в значительно больших масштабах, чем иезиевым, а именно, в

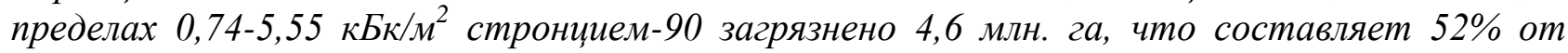
обследованной площзади.

Результаты исследований свидетельствуют, что общая площадь загрязненных земель в Украине составляет около 9 млн. га, из них 4,2 млн. га - радиационно загрязненные, 2,0 млн. га - загрязненные тяжелыми металлами, 2,8 млн. га - загрязненные токсикантами органического и неорганического происхождения. Установлено, что загрязнение тяжельми металлами с агропромышленных источников до уровней, приближаюшихся к максимально допустимых (МГС), возможно только на землях, на которых средства химизации применяли длительное время без должного контроля. A также установлено, что внесение минеральных удобрений и традиционных органических удобрений в средних дозах способно поднять уровень содержания тяжелых металлов в почвах с действующими в настоящее время значений МДК только за сотни лет.

Ключевые слова: почва, минеральные удобрения, радионуклиды, пестициды, тяжелье металль, загрязнения.

Табл. 3. Лит. 15. 


\section{Information about the authors}

Яковець Людмила Анатоліївна - кандидат сільськогосподарських наук, старший викладач кафедри ботаніки, генетики та захисту рослин Вінницького національного аграрного університету, (21008, м. Вінниця, вул. Сонячна, 3. e.mail: ludmila28334@gmail.com).

Яковец Людмила Анатольевна - кандидат сельскохозяйственных наук, старший преподаватель кафедры ботаники, генетики и защиты растений Винницкого национального аграрного университета, (21008, г. Винница, ул. Солнечная, 3 e.mail: ludmila28334@gmail.com).

Yakovets Liudmyla - Candidate of Agricultural Sciences, Senior lecturer of the, department of Botany, Genetics and Plant Protection of Vinnytsia National Agrarian University, (21008, Vinnytsia, Soniachna St. 3, e.mail: ludmila28334@gmail.com). 